\title{
FOGYASZTÁSI SZÖVETKEZETI KERESKEDELEM ÉS GAZDASÁGPOLITIKA TEGNAP, MA ÉS HOLNAP
}

\author{
(Consumer's Cooperation's Trade and Economical Policy \\ Yesterday, Today and Tomorrow) \\ GÉRÓ IMRE
}

Kulcsszavak:

konvergencia gazdaságpolitika fogyasztási szövetkezeti kereskedelem gazdasági növekedés versenyképesség szervezeti innováció

Az általános fogyasztási és értékesitö szövetkezetek (az áfészek) különleges társadalmi, gazdasági képzödmények. Az adott korszak viszonyai határozzák meg lényegüket. Napjainkban ezért azt hibásan, eltérö (változó) nézöpontból közelítik.

A magyar fogyasztási szövetkezeti kereskedelem a rendszerváltást megelözöen komoly gazdasági, gazdaságpolitikai pozicióval rendelkezett Magyarországon, különösen a vidék lakosságának életminösége fejlesztésében, az életszinvonal fejlödésében. Meghatározó szerepe volt a kereskedelmi ellátás és ellátottság, de az agrárgazdaság, az agribiznisz tekintetében is. A politika, a rendszerváltást követöen, - bizonyos tekintetben a gazdasági racionalitás fölé kerekedve - a korábbi szövetkezeti értékeket majdhogynem teljesen megsemmisitette. A fogyasztási szövetkezetek „ösi értékei”, szervezeti innovációs képessége stb. eredményeként sikerült egy pozitiv konvergencia folyamatot elinditani, amely hol eröteljesebben, hol kevésbé eröteljesen konvergált az aktuális gazdaságpolitika hazai prioritásaival. A szerzö enneǩ a folyamatnak̉ a föbb jellemzöit elemzi tanulmányában.

\section{Bevezetö}

Az általános fogyasztási és értékesító szövetkezetek (az áfészek) különleges társadalmi, gazdasági képződmények. Az adott korszak viszonyai határozzák meg lényegüket. Napjainkban ezért azt hibásan, eltérỏ (változó) nézỏpontból közelítik. Még mindig fel-felbukkan az a hiedelem, hogy az áfészek és szervezeteik marginalizálódtak. Ez tíz évvel ezelött igaznak tünhetett. A szövetkezés ellenzöi, illetve a piaci konkurencia részéról terjesztett szirén hangokra ma a tények adják a leghitelesebb választ. E szerint: az áfészek és társaságaik, egyéb érdekeltségeik az egész országot behálózzák; tagságuk a lakosság valamennyi rétegéböl verbuválódik; a tehetősebb és a szerényebb tagjaik számára egyaránt ígéretes vállalkozási formák; csakis magyar tőkével müködnek; sikeres szereplői a hazai kereskedelmi piacnak; versenyképesek a multinacionális kereskedelmi üzletláncokkal, hálózatokkal; teljesítményük szerint, müködésük körében a magyar kereskedelemben az első három hazai piaci szereplö között foglalnak helyet; vásárlóikat visszatérítésben részesítik; a demokrácia iskoláinak tekinthetők; kereteik között az önigazgatásban széles tömegek vesznek részt; létük, müködésük és jövöjük társadalmi érdekkel kapcsolódik 
Géró Imre : Fogyasztási szövetkezeti kereskedelem és gazdaságpolitika tegnap, ma és holnap.

Tér és Társadalom 22. évf. 2008/2. 145-167. p.

146 Gyors ténykép

TÉT XXII. évf. 2008 @ 2

össze. A falusi problémák társadalmi eredetúek, az itt élő népességnek jelenleg nincs hathatós szervezett ereje, jórészt elvesztette érdekérvényesítő képességét, noha neki is joga van olyan életminöségre, mint a városiaknak. Az ,élhető falu" jelszavának zászlaja alatt, ezért nemzeti mozgalommá kell tennünk a vidék ügyét. Az általános fogyasztási és értékesítő szövetkezetek (az áfészek) és közös szervezeteik történetét, átalakulását, illetve jövőjét e nézópontból is vizsgáljuk.

Az ENSZ, az SZNSZ, az EU felhívásai, legutóbb a Nemzetközi Munkaügyi Hivatal 2002. június 20-án Genfben megtartott 90. ülésszakán ,a szövetkezetek elősegítéséről” elfogadott ajánlása, ilyen értelemben történő cselekvésre hívják fel a nemzeti kormányok figyelmét is.

\section{A gazdasági felzárkózás - konvergencia - néhány növekedéselméleti összefüggése $e^{l}$}

A gazdasági növekedés elméletében az 1980-as évek második felétől kibontakozó forradalom a nemzetgazdaságok növekedési folyamatainak rendkívül kifinomult és precíz elemzését, valamint az empirikus tényekkel konzisztens elméletek kialakulását egyaránt magával hozta (Dedák 2003). Mindennek eredményeként a modern növekedéselmélet a gazdasági felzárkózást végrehajtó országok számára számos tanulsággal szolgál, s egyúttal iránymutatásokat is tartalmaz arra vonatkozóan, hogy melyek azok a makrogazdasági területek, amelyekre a gazdaságpolitikának megkülönböztetett figyelmet kell fordítania. A gazdasági felzárkózás elméleti összefüggéseinek különös relevanciát kölcsönöz az a tény, hogy a kelet-európai átalakuló gazdaságok többségében a gazdasági transzformációval együtt járó visszaesést követöen eröteljes növekedés indult meg az 1990-es évek közepén, illetve második felében. A megindult növekedés ellenére mégis meglehetősen sok bizonytalanság és kérdés merül fel a felzárkózási folyamatot illetően. A problémák többnyire a növekedés tartósságával, a felzárkózás lehetséges időtartamával és a gazdasági növekedési ütem konkrét nagyságával kapcsolatosak. Véleményünk szerint, különösen a felzárkózás időtartamával és a növekedési ütemmel kapcsolatosan sok esetben a közgazdasági realitásokat nélkülöző következtetések fogalmazódnak meg. A magyar gazdaság felzárkózása szempontjából néhány releváns növekedéselméleti tanulságot kísérlünk meg összefoglalni, s kitérünk a hazai gazdaság növekedési folyamatait befolyásoló néhány makrogazdasági problémára is.

\section{Néhány általános tanulság}

Gazdaságpolitikai szempontból három tanulság vonható le az elmúlt évtizedek makrogazdasági tapasztalatai alapján:

1) Az első - és gazdaságpolitikai szempontból talán a legfontosabb tanulság -, hogy a gazdasági felzárkózás nem megy végbe automatikusan. Nem mủködnek olyan makrogazdasági automatizmusok, amelyek a fejletlen vagy közepesen fejlett 
Géró Imre : Fogyasztási szövetkezeti kereskedelem és gazdaságpolitika tegnap, ma és holnap.

Tér és Társadalom 22. évf. 2008/2. 145-167. p.

TÉT XXII. évf. 2008 a 2

Gyors ténykép

országok jövedelmi színvonalát a fejlett országok szintje felé terelnék. A „laissez faire" sok területén érvényesülö elvei a gazdasági felzárkózás tekintetében hatástalanok. A növekedéselméleti összefüggések értelmében minden ország a rá jellemző makrogazdasági paraméterek - melyek közül a megtakarítási ráta, a humán tőke és a népesség növekedési üteme tekinthetök fundamentálisnak - által meghatározott jövedelmi helyzethez (steady-state) konvergál. Ha például két ország ugyanazokkal a makrogazdasági paraméterekkel rendelkezik, de az induló jövedelmi pozíciójuk eltérő, akkor hosszú távon ugyanahhoz a jövedelemszinthez konvergálnak, bármilyen jelentősek is voltak a kezdeti jövedelmi különbségek. Ezért azok a gazdaságpolitikai intézkedések, amelyek kedvező irányba mozdítják a növekedést befolyásoló fundamentális tényezőket, jelentôs mértékben elősegíthetik a sikeres felzárkózást a fejlett országok jövedelmi színvonalához.

2) Amennyiben a gazdaságban a piaci viszonyok és a magánszektor dominanciája meghatározó, valamint a gazdaság nyitott és egyre intenzívebben integrálódik a világgazdaságba, továbbá a vállalati szektor profitabilitása megfelelő, akkor a nemzetgazdasági szintủ megtakaritási (beruházási) ráta alakulása a gazdasági felzárkózás egyik kulcsváltozỏja. A gazdasági felzárkózást és a tartós gazdasági növekedést elősegíteni igyekvő gazdaságpolitikának ezért a megtakaritások ösztönzését prioritásként kell kezelnie. A megtakarítások ösztönzését (pl. a befektetési adóhitel kiterjesztésével vagy más eszközökkel) a tartós gazdasági növekedésre törekvő kormányzatnak az egyik legfontosabb gazdaságpolitikai célkitüzésként kell kezelnie.

3) Az ủj keletú növekedéselmélet egyik legfontosabb mondanivalója, hogy a fizikai értelemben vett töke javak mellett a humán tőkének is kulcsfontosságú szerepe van a GDP alakulásában. Ez utóbbi figyelembe vétele nélkül az országok közötti jövedelmi különbségek nem érthetők meg. Axiómaként kell kezelnünk azt a tételt, hogy magas szintü (20\%-ot jóval meghaladó) beruházási rátára van szükség, de axiómának - és nem valamiféle szlogennek - tekinthetỏ az is, hogy a humán töke felhalmozását elősegítő erőforrásokat növelni kell. A hazai állapotokat tekintve ez utóbbi terén bőven akad tennivalónk. Szemléletváltásra és meggyőződésünk szerint a finanszírozási formák újragondolására egyaránt szükség van.

\section{Szükséges feltétele-e az államadósság leszoritása a gazdasági felzárkózásnak?}

Míg az államadósság/GDP hányados 1995-ben 86,5\%-ra rúgott, 1999-ben $(59,4 \%)$ már alatta maradt a maastrichti konvergencia-kritériumokban meghatározott $60 \%$-os referenciaértéknek, az előzetes becslések szerint a mutató értéke az elmúlt évben tovább romlott. Joggal vetődik fel a kérdés, hogy az államadósság/GDP érték változásának mekkora szerepe van az utóbbi években nálunk megvalósult tekintélyes mértékú gazdasági növekedésben. Valóban elengedhetetlen feltétele-e az állam eladósodásảnak mérséklése a gazdasági felzárkózásnak? Az adósságdinamikai és a növekedéselméleti összefüggések összekapcsolása jó magyaráza- 
Géró Imre : Fogyasztási szövetkezeti kereskedelem és gazdaságpolitika tegnap, ma és holnap.

Tér és Társadalom 22. évf. 2008/2. 145-167. p.

tul szolgál arra vonatkozóan, hogy miért rendelkezhetnek lényegében azonos fejlettségi szinten lévő országok rendkívül eltérő mértékű kormányzati eladósodással. Az elmondottakból az is következik, hogy egy közepesen fejlett ország - mint például Magyarország - esetében - egyes mértékadónak tekinthető makro-közgazdászok véleménye szerint - nem sorsdöntő a gazdasági felzárkózás tekintetében az, hogy a költségvetés hosszú távon kiegyensúlyozott-e, vagy szerény mértékủ deficitet mutat, és ezáltal az államadósság alacsony, vagy a GDP-hez mérten viszonylag magas értéken állandósul.

\section{A gazdasági növekedés üteme és a felzárkózás időtartama}

A felzárkózás időtartama és a gazdasági növekedés üteme szempontjából a konvergencia sebességének $(\beta)$ van döntő jelentősége. Ez azt fejezi ki, hogy a gazdaság milyen gyorsan közelít az új, kedvezöbb relatív jövedelmi pozíciót biztositó növekedési pályához. Minél nagyobb a $\beta$ értéke, a felzárkózás annál rövidebb idő alatt valósulhat meg, $\mathrm{s}$ annál magasabb lehet a gazdaság növekedési üteme a felzárkózás folyamán. Az empirikus elemzések (Barro-Sala-i-Martin 1992; Mankiw et al 1992) a konvergencia sebességét $2 \%$ körülire teszik, vagyis a felzárkózó ország évente a meglévő lemaradás $2 \%$-ával kerül közelebb ahhoz a relatív jövedelmi szinthez, amelyre a felzárkózás történik.

A felzárkózás kezdetén Magyarország a fejlett EU-országok jövedelmének 45\%-ával rendelkezett, félúton viszont már 73\%-ával. Ehhez a gazdaság $\beta$ (konvergencia) értékét 2,1\%-nak véve - 33 évre van szüksége.

Mindez rögtön azzal a tanulsággal szolgál, hogy a gazdasági felzárkózás megvalósítása idôigényes, több évtizeden keresztül elhúzódó feladat. A konvergencia sebességének alacsony értéke következtében az új, kedvezőbb relatív jövedelemszint elérése csak lassan megy végbe. Mindez a gazdasági felzárkózást megkezdő országok számára meglehetősen lehangoló következtetésnek tekinthető. Az eredmények értelmezésével azonban körültekintően kell eljárni. A felzárkózás során a jövedelmekben meglévő relatív lemaradás csökken, miközben a fejlett országok gazdasága is növekszik.

A hazai gazdasági felzárkózási folyamat, az új növekedési pályához való konvergálás 1997-től kezdődött. 1997-ben a GDP 4,6\%-kal, 1998-ban 5,1\%-kal,1999-ben 4,5\%-kal nött, míg 2000-ben 5,7\% körüli növekedés volt. A felzárkózás kezdeti éveiben tehát a GDP átlagosan mintegy 5,0\%-kal növekedett évente.

Az elméleti összefüggéseken túlmenően ez is azt valószinüsíti, hogy az elkövetkezö években a növekedési ütem fokozatos csökkenésére kell számítanunk. A mi helyzetünkben azonban a 4\%-hoz közeli növekedési ütem nem a felzárkózás elakadását jelenti, hanem azt az ütemet, amelyre a jelenlegi fejlettségi szintünk alapján a felzárkózás kezdeti periódusában reálisan számíthatunk. 
Géró Imre : Fogyasztási szövetkezeti kereskedelem és gazdaságpolitika tegnap, ma és holnap.

Tér és Társadalom 22. évf. 2008/2. 145-167. p.

TÉT XXII. évf. 2008 - 2

Gyors ténykép

\section{A gazdaságpolitika funkciói}

Az állam szerepét a méltán klasszikussá vált Adam Smith egyik alapmüvében három fö területre terjeszti ki:

1) A társadalom védelme külső támadásokkal szemben.

2) Annak megakadályozása, hogy a társadalom tagjai között igazságtalanságot jelentő, illetve elnyomási viszonyok alakuljanak ki (Smith 2007).

3) Olyan kiadások eszközlése, valamint olyan intézmények létrehozása, amelyek a társadalom többségének érdekeit szolgálják.

Nem kétséges, hogy a legtöbb vitát a harmadik pont váltotta és váltja ki máig is. Mindez tulajdonítható elsősorban annak, hogy a 3) pontban foglaltak mennyiségi és minőségi kategóriát egyaránt jelentenek.

Lord Káldor egyik mủvében szemléletesen mutatja be a II. világháború utáni angol gazdaságpolitika szerepkörének bövülését (idézi Veress et al 2001). A háború után elöször a teljes foglalkoztatottság igénye merült fel. Később a fizetési mérleg stabilitása, azaz az eladósodás megakadályozása is fontos céllá vált. Ezt követte a dolgok természetes logikájából fakadóan a növekedés, mint cél. Ezután a bérnövelési, jövedelempolitikai előirások megfogalmazása, vagyis a jövedelem aránytalanságok kiküszöbölése vált szükségessé. Ezt a célt követte később a valuta értékállandóságának biztosítása, mint alapvető prioritás.

A gazdaságpolitika kulcsproblémái napjainkra, azt lehet mondani, hogy kijegecesedtek. A gazdasági növekedést, a foglalkoztatottság minél magasabb szintjét, a valuta értékállandóságának biztosítását, a fizetési mérleg kiegyensúlyozott voltára való törekvést és a jövedelmi aránytalanságok korlátok között tartását tekinthetjük azoknak a legfontosabb gyakorlati gazdaságpolitikai céloknak, amelyek egyúttal a kulcsfeladatokat is jelentik.

Samuelson és Nordhaus négy gazdaságpolitikai funkciót különböztet meg (idézi Veress et al 2001):

- A jogi keretek biztosítását.

- A makroökonómiai stabilizációs politika meghatározását.

- Az erőforrások elosztásának a gazdasági hatékonyság fokozását célzó befolyásolását.

- A jövedelemelosztást befolyásoló programok kidolgozását.

Általános érvényủ tudományosságában vizsgálva a kérdést, a kilencvenes években a közgazdászok és a társadalomtudósok között egyetértés volt abban, hogy a következö öt funkció sorolható a gazdaságpolitika felségterületei közé:

1) A jogi és a társadalmi keretek biztosítása.

2) A verseny fenntartása.

3) A jövedelmek ủjraelosztása (redisztribúció).

4) Az erőforrások átcsoportosítása (allokáció).

5) Stabilizáció. 
Az állami szerepvállalás kétségtelenül meglévő és fellelhető hiányosságairól külön is kell szólni. Beszélhetünk piaci hibákról (market failures) és kormányzati hibákról (government failures). Joseph Stiglitz szerint a kormányzati hibák főbb okai a következökben foglalhatók össze (idézi Veress et al 2001):

1) Sok állami akció igen bonyolult és következményeit illetỏen nehezen elörelátható.

2) A kormányzatnak csak korlátozott ellenőrzési lehetőségei vannak döntéseinek konzekvenciáit illetően. (Különösen a demokrácia keretein belül.)

3) Azok, akik a törvényhozásban ülnek, a program alkalmazását illetően csak kevés kontrollal bírnak.

4) A politikusok és mindazok, akik a köz szolgálatában állnak, igen gyakran érdekeltnek érzik magukat a tekintetben, hogy speciális érdekcsoportok hasznára cselekedjenek. Ez többé-kevésbé objektív tény is befolyásolhatja a célok és a következmények viszonyát is.

\section{Az átmenet általánositható tapasztalatai a kelet-európai térségben}

Több kikristályosodott tapasztalat gyülemlett fel a kilencvenes évek végéig. Az első és legszembetủnőbb az, hogy a politika - más módon ugyan, mint a korábbi monolit társadalmakban - rátelepedett a gazdaságra. Az újabb eredeti tőkefelhalmozás során számos szálon érezhető, hogy a vezető politikai erök gazdasági döntéseit erős érdekérvényesítók jelentösen befolyásolják. A parlamenti színtér pedig sorozatosan bizonyítja, a belpolitikai viszályokon a politikai pártok nem képesek felülemelkedni.

A második tapasztalat: immár biztos, hogy az átmenet nem közép-, hanem sokkal inkább hosszú távú folyamat, vagyis az átmenet hosszabb, mint ahogy azt a politikai fordulat idején sokan prognosztizálták. Az átmeneti időszak végét az jelzi majd, ha az ország gazdasági rendszerét a modern piacgazdaságokra jellemzö paraméterekkel lehet leírni.

A harmadik tapasztalat az, hogy a privatizáció szükséges, de nem elégséges feltétele a piacgazdaságnak. Tartós versenyképesség, valós tőkepiac, hatékony versenyszerkezet és következetes stratégiai keretek között tartott, piackonform kormányzati rásegítő lépések nélkül nem alakulhat ki múködőképes piacgazdaság.

A negyedik tapasztalat az, hogy a transzformáció során sehol sem használhatók fel közvetlenül, tiszta formában a közgazdasági iskolák ajánlásai és a piacgazdasági modellek.

Az ötödik tanulság az, hogy a hivatalos gazdaságpolitika és annak gyakorlata között hasonló rés tátong, mint a korábbi társadalmi berendezkedés során.

A hatodik tapasztalat az, hogy az átmenet országaiban, így Magyarországon is túlértékelték a fejlett világ szerepét a gazdaság talpra állításában és modernizációjában. A régió jelentősége - az idő múlásával - a Nyugat szemében több okból is csökkent. A kilencvenes években a fejlett országokat is elérte a recesszió; természetesen a miénkhez képest lényegesen kisebb nagyságrendben, Magyarország megité- 
Géró Imre : Fogyasztási szövetkezeti kereskedelem és gazdaságpolitika tegnap, ma és holnap.

Tér és Társadalom 22. évf. 2008/2. 145-167. p.

TÉT XXII. évf. 2008 — 2

Gyors ténykép

151

lése a politikai fordulat előtt lényegesen kedvezőbb volt potenciális versenytársainkénál, illetve valós sorstársainkénál. Kiderült: lényegében minden ország csak magára számíthat.

\section{Versenyképesség - gazdaságpolitika-prioritás}

A versenyképességi koncepció (2005) alapján a „versenyképesség” definíciója a következö: Versenyképesség a gazdasági, politikai, társadalmi rendszer képessége a fenntartható gazdasági növekedés tényezőinek felhalmozására, illetve az ezek érvényesülését elősegítő makrogazdasági stabilitás és mikrogazdasági ösztönzőrendszer biztosítására.

A növekedési tényezök fejlesztése által vélt és elvárt hatások érvényesüléséhez az aktuális magyar kormányzati versenyképességi koncepció három gazdaságpolitikai alapfeltétel,

- a makrogazdasági stabilitás,

- a kormányzati szektor szerkezetének és müködésének átalakítása, illetve

- az intézményrendszer és piacszabályozás

területén jelöl ki teendöket.

A versenyképességi koncepció alaptézise: Magyarországon a gazdaságpolitikának

- a foglalkoztatás bővítésére,

- a humán tőke minőségi mutatóinak javítására,

- a fizikai tőke minőségének javítására, azaz az innováció, infrastruktúra és kutatás-fejlesztés erősítésére, illetve

- a beruházások ösztönzésére

kell törekednie.

A tartós növekedés tényezöi a versenyképesség erösitése mellett elösegítik a társadalmi kohéziót és a fenntartható fejlődést, egyúttal összhangban vannak a regionalizmus szempontjaival.

A versenyképességi koncepció (2005) további ajánlása, hogy az állam gazdaságpolitikája nem szólhat az állam által kijelölt nyertes és támogatandó ágazatokról, de a gazdaságpolitikának rendelkeznie kell viziókkal, amelyek jelzik, hogy mely ágazatok lehetnek a gazdasági növekedés húzóterületei. A fejlesztési prioritások olyan szüröként is alkalmazhatók, amelyek segítségével meg lehet határozni, hogy egy ágazat fejlődése miképpen képes keresleti oldalról erösíteni a gazdaság versenyképességét. Amennyiben valamelyik ágazat hozzájárul a tartós növekedés tényezőihez, a gazdaságpolitikának érdemes közvetett eszközökkel (kedvezö befektetési környezet kialakitása, $K+F$-re és innovációra ösztönzö szabályozási környezet, kompetitív piaci szerkezet fenntartása, hatékony szabályozás) figyelmet forditani a tartós növekedés szempontjából ígéretes ágazatokra.

A versenyképességi koncepció mentén elvégzett ágazati elemzések kimutatták, hogy vannak olyan ágazatok, amelyek a hazai gazdaság növekedésében a jövőben is meghatározó szerepet játszhatnak, mert több fejlesztési prioritást „húznak” fejlö- 
Géró Imre : Fogyasztási szövetkezeti kereskedelem és gazdaságpolitika tegnap, ma és holnap.

Tér és Társadalom 22. évf. 2008/2. 145-167. p.

désükkel, míg mások kevesebb fejlesztési prioritást ösztönöznek. Az előbbi csoporthoz tartozik például az IKT-eszközök és szolgáltatások elöállitása, az egészségipar, a specializált turizmus, a széles tovagyürüzö (beszállítói) hatásai miatt a jármüipar, illetve az üzleti szolgáltatások és a logisztika. Az utóbbi csoporthoz sorolható például az élelmiszeripar, a környezetipar, a müanyagipar és a szórakoztatóipar.

A versenyképességi koncepció kialakítása során figyelembe vették azt a tényt, hogy a magyar gazdaságra jelentős területi különbségek jellemzök. A regionális eltérések megnyilvánulnak a növekedési tényezőkkel való ellátottságban, a versenyképességi mutatók alakulásában, a növekedési tényezők és fejlesztési prioritások adott régió kohézióját és versenyképességét erősitő hatásaiban.

A regionális elemzések jelentős eltéréseket tártak fel a régiók versenyképességi helyzetét, a tartós növekedés tényezőivel való ellátottságukat, valamint a versenyképességi jövöképüket illetően. Az elemzések keretében feltárásra kerültek a magyarországi régiók közötti tényezö-ellátottságot érintő különbségek, valamint a lehetséges (javasolt) fejlesztési prioritások. A jelentős eltérések folytán megfontolandó bizonyos prioritások regionális kiszervezése (pl. beszállítói program, az FDI- és KKV-vonzó beruházások támogatása, az innovációs készségek fejlesztése, az oktatás és gazdaság közötti kapcsolatok erôsítése). Míg olyan fejlesztési prioritások mentén, amelyek azonos formában és tartalommal jelennek meg az egyes régiókban (pl. a közlekedés fejlesztése vagy a szélessávú infrastruktúra, szakképzés támogatása) nagyobb áttörési lehetöséget ígérnek a központilag vezetett programok.

$\mathrm{Az}$ Európai Unió által nyújtott források felhasználása koncentrált, a növekedés szempontjából meghatározó tovagyürüző hatásokkal rendelkezö területekre irányuló kell, hogy legyen. Ez minél kevesebb, minél jobban célzott operativ programot igényel a hazai hatóságok részéról.

A versenyképességi koncepció kiterjed az Európai Unió által nyújtott források felhasználásának elemzésére.

Figyelembe véve a növekedési tényezőket, valamint az ebböl meghatározott fejlesztési prioritásokat, célszerünek tủnik öt jelentösebb cél kiemelése és finanszirozása az EU-s forrásokból:

- oktatás és képzés,

- a foglalkoztatást növelő fejlesztések,

- K+F és innovációs infrastruktúra fejlesztése,

- az információs társadalom infrastruktúrájának kialakítása és

- a tágan értelmezett közlekedési infrastruktúra fejlesztése.

A versenyképességi koncepció alapja a tartós növekedés tényezőit definiáló új növekedési elméletek, amelyek kiemelik a versenyképességben és növekedésben meghatározó tényezöket, és bemutatják a növekedés gazdaságpolitikai, intézményrendszeri és szerkezeti előfeltételeit.

Következésképp, a versenyképességi koncepció egyik pillére a tartós növekedés tényezöinek:

- a foglalkoztatásnak, 
- a beruházásnak,

- a humán tőkének,

- a fizikai töke minőségének (innováció, infrastruktúra és kutatás-fejlesztés),

- a termelékenységnek

a vizsgálata abból a szempontból, hogy e tényezők közül melyek szabadíthatnak fel jelentős növekedési tartalékokat Magyarország esetében. A koncepció másik pillére azon gazdaságpolitikai alapfeltételek megfogalmazása, amelyek teljesülése szükséges ahhoz, hogy a tartós gazdasági növekedés tényezöinek fejlesztése által vélt és elvărt hatások érvényesüljenek.

\section{A szervezeti innováció és versenyképesség fogalma regionális aspektusból}

Az innováció a vállalati megújulás forrása. Mivel a versenyelöny források mindegyikére jelentős hatása van, ezért a piaci siker elérésének fontos tényezöje. A tanulási görbe a munkaerő tapasztalatszerzésével és a termék-, illetve technológia tökéletesedésével összefüggő jelenség. A tanulási görbére épített stratégia segítségével eredményesen megakadályozható új versenytársak piacra lépése, és gyorsan növelhetó a piaci részesedés.

Az innovációnak számtalan definíciója létezik a szakirodalomban (Chikán 1997). A legtágabb értelmezés szerint az innováció a fogyasztói igények kielégitésének új, a korábbinál magasabb minőségü módja. Konkrét megjelenési formái az új termékek, új termelési eljárások, új szervezeti formák.

\section{Az innováció versenykörnyezetének jellemzői}

A mai dinamikus gazdasági környezetben az ủj termékek és termelési eljárások kifejlesztése döntő tényezöje a vállalati versenynek. E téren ma azok a vállalatok lehetnek versenyképesek, amelyek egyre rövidebb idő alatt képesek kifejleszteni új termékeket a költségek növekedése és a minőség feláldozása nélkül (ChikánDemeter 2003).

A tanulási görbe a felhalmozódó termelési tapasztalat és a költségek csökkentése közötti kapcsolatot írja le.

\section{A keresletorientált regionális stratégia}

A keresletorientált regionális fejlesztési stratégia (Rechnitzer 1998) „a térséget egységes egészként kezelve, annak belső sajátosságaiból, a térségen belülról kiindulva, egyre jobban kifelé haladva, mind több külső tényezőt figyelembe véve" (Korompai 1995, 69) kerül meghatározásra és egyben müködtetésre. A helyi területi gazdaság megújításánál nem csupán a külső (exogén) forrásokra támaszkodik, ha- 
nem felméri és számba veszi a belső adottságokat, azokat újraértékeli éppen a külső piaci rendszerek által, s így keresi versenyképességük fokozásának lehetőségeit.

\section{A hálózatok}

A keresletorientált fejlesztési stratégia egyik meghatározó eleme a helyi-területi hálózatok alakítása. A teljesítmény kényszert csak úgy lehet elérni, ha nem a versenytárs legyözését tüzik ki célul, hanem keresik az együttmüködés, a kooperáció új tereit, amivel az erőforrások körét bövíthetik, $\mathrm{s}$ ezzel a megújítás formáit is szélesíthetik. Ez a felfogás szükségessé teszi az egyre „laposabb” vállalati irányítást, a profitcentrumok kialakítását, a helyi-térségi együttmüködéseket serkentỏ vállalati rendszerek terjedését. A régió meghatározásokat célszerú lesz a jövőben hálózatok alapjản is értelmezni. A hálózati szemléletre épülő regionális fejlesztési stratégia tehát azt szorgalmazhatja, hogy:

- A területi egységben a belső, újszerủ kapcsolatok minél több szinten jöjjenek létre, $\mathrm{s}$ ezzel a regionális jelleg szélesedjen (hálózat építés);

- A térségben meglévő hálózatok erösödjenek, új mozgástereket nyerjenek, vagy éppen megújuljanak (hálózat fejlesztés);

- Történjen meg a területi egység rákapcsolása egy vagy több, éppen a hálózati elven müködő, vagy azt tükröző régióra, hasznosítva és egyben szélesítve azok hálózati rendszereit (hálózatok összekapcsolása!!!) (Rechnitzer 1998, 32)

\section{Az innovációs miliő}

A keresletorientált regionális stratégiában a hálózati jelleg szükségszerúen együtt jár az innovációs miliő kialakulásával. Az innovációs miliő alatt egyik oldalról azoknak - az adott földrajzi területen felismerhető - gazdasági, termelési kapcsolatoknak a csoportját lehet tekinteni, amelyek egységességet alakítanak ki a termelési rendszerben a gazdasági szereplők között és a termelési kultúrában. A kollektív tanulással - helyileg meghatározott formában - hozzájárulnak az innovációs folyamatok terjesztéséhez, s egyben csökkentik a piaci kapcsolatok bizonytalanságait, növelik a termelő egységek és a területi gazdaság versenyképességét. Az innovációs miliő́t másik oldalról azok a helyi kultúrában, társadalmi kapcsolatokban és az intézményrendszerben meglévő sajátosságok is képviselik, amelyek mind a gazdaságon keresztül, mind a helyi-területi szereplőkön át, folyamatosan hozzájárulnak az újdonságok kialakításához, azok megtelepedéséhez és részben terjesztéséhez.

Az áfész-ek regionális szerveződésủ hálózatainak fontos szerepe volt, van és lesz a jövőben is a fenti alapelveket szem elött tartó innovációs miliő fejlesztésében, hagyományos szövetkezeti értékeikre és alapelveikre épülô integrált szervezetrendszerük révén.

A szervezeti innováció és versenyképesség szövetkezetekre történő adaptálásához néhány további fontos elméleti kitekintés szükséges. A témával foglalkozó szakirodalomban, az utóbbi időben egyre több szakkönyv és tanulmány igyekszik bebizo- 
Géró Imre : Fogyasztási szövetkezeti kereskedelem és gazdaságpolitika tegnap, ma és holnap.

Tér és Társadalom 22. évf. 2008/2. 145-167. p.

TÉT XXII. évf. $2008 \mathbf{m} 2$

Gyors ténykép

155

nyítani, hogy a szervezeti kultúra milyen fontos szerepet játszik a szervezetek kiváló teljesítményében (Ben Ami-Farkas 2003). Érdekes gondolatot vetett fel elsöként Ghemawat (1986) újszerü tipológiájával. Véleménye szerint a támadható előny könnyen utánozható, éppen ezért csupán rövid ideig fejti ki hatását. Ezzel szemben a fenntartható elönyt jóval nehezebb utánozni, ezért sokkal tovább hatásos marad. Megállapíthatjuk tehát, hogy annál jobb, minél több fenntartható előnnyel rendelkezünk. Collis és Montgomery (1995) a versenyelőnyök osztályozására még egy ennél is érzékenyebb tipológiát javasol. Ők az előnyöket azok utánozhatatlansága, időtállósága, helyénvalósága, behelyettesíthetősége és versenyfölénye alapján osztályozzák. Hogy hol és hogyan lehet megszerezni ezeket az előnyöket, erre a tudomány alapvetően két csoportba sorolható választ ad. Az egyik csoportba azok tartoznak, amelyek inkább a külső környezetre koncentrálnak (ez a stratégia klasszikus megközelítése), a másik csoportot pedig azok alkotják, amelyek magának a szervezetnek a forrásaira és képességeire helyezik a hangsúlyt (ez a stratégia új megközelítése). A fogyasztási szövetkezeti kereskedelem szervezeti innovációs folyamatában, véleményünk szerint, a szervezeti kultúra alapvető értékeinek és alapelveinek érvényesülése miatt természetes módon az utóbbi, a stratégia új megközelítése érvényesült. A szervezetfejlesztés Bennis szerint a változásra adott válasz, egy komplex oktató stratégia, melynek célja megváltoztatni a szervezet hiedelmeit, attitủdjét, értékeit, struktúráját, annak érdekében, hogy jobban tudjon alkalmazkodni az új technológiákhoz, piacokhoz, kihívásokhoz és a szédítỏ ütemú változásokhoz (Bennis 1969), tehát nem vitás, hogy a szervezetek stratégiáját is érintö folyamat, melyben a beavatkozások célja a problémák megoldása, vagy lehetőségek kihasználása. A szervezetfejlesztés a változás menedzselésének egyik módszere, mely a struktúra átalakítása helyett/mellett nagy hangsúlyt fektet az emberi tényezöre, ezen belül a csoportok és az egész szervezet hatékony müködésére (Dobák 1996). Tehát a fejlesztés iránya ebben az esetben a csoport és az egész rendszer. A szervezetfejlesztési beavatkozások leggyakrabban a kulcs szerepekre, a csoportokra, a csoportok kőzőtti együttmúködésre és a szervezet egészére irányulnak (Miles-Schmuck 1989). Általánosságban megállapítható, hogy a szervezetek változásának menedzselése a vezetők feladata. Sokféle módon lehet a szervezeteket változtatni. A szervezetfejlesztés, a szervezeti innováció a változás menedzselés ember központú megközelítése. A szervezeti kultúra a szervezet tagjai által közösen vallott és követett értékek, hiedelmek összessége (Bakacsi et al 1999). A kultúra támogathatja, elősegítheti a szervezetfejlesztés módszerének alkalmazását, de meg is akadályozhatja azt. Nem véletlen, hogy Burke (1994) a szervezetfejlesztést a szervezeti kultúra változtatási folyamataként definiálja. 
Géró Imre : Fogyasztási szövetkezeti kereskedelem és gazdaságpolitika tegnap, ma és holnap.

Tér és Társadalom 22. évf. 2008/2. 145-167. p.

\section{A fogyasztási szövetkezeti (ÁFÉSZ) kereskedelem szervezeti innovációjának evolúciója a rendszerváltást követöen}

\section{A fenntartható fejlödés fogalma}

A szociális és a környezeti problémák fontosságának, e problémák, illetve megoldási lehetőségeik és a gazdasági fejlődés közötti sokrétü összefüggések felismerésével egyre inkább teret nyertek azok a nézetek, amelyek szerint e három területet együtt kell vizsgálni, s sajátosan a környezet és fejlesztés kérdéseinek együttes megközelítése szükséges. A nyolcvanas évek elején jelent meg a 'fenntarthatóság' vagy a 'fenntartható fejlődés' kifejezés a nemzetközi szakirodalomban. Általános ismertségét Lester R. Brown (2001) a fenntartható társadalom kialakításával foglalkozó mủve váltotta ki, amely 1981-ben jelent meg. A szerzö összekapcsolta a népesség növekedését a természeti erőforrások hasznosításával, és mindezt úgy kívánta megoldani, hogy a lehető legkisebb legyen a természeti környezet mennyiségi és minőségi romlása. 1983-ban az ENSZ Közgyülés határozata alapján megkezdte munkáját az ENSZ Környezet és Fejlődés Világbizottsága, amelyet Gro Harlem Brundtland, norvég miniszterelnöknő vezetett. (E huszonkét tagú bizottságnak tagja volt Láng István akadémikus is.) A Bizottság 1987-ben „Közös jövőnk” címmel kiadott jelentésében a gazdasági növekedés olyan új korszakának lehetőségét vázolta fel, amely a fenntartható fejlődés globális megvalósitására épít, megőrzi a természeti eröforrásokat, $\mathrm{s}$ amely megoldás lehetne a fejlödő országok nagy részében elhatalmasodó szegénység leküzdésére is. A jelentés nagyon röviden és tömören határozta meg a fenntartható fejlődés fogalmát: a fenntartható fejlödés olyan fejlödés, amely kielégiti a jelen szükségleteit, anélkül, hogy veszélyeztetné a jövö nemzedékek esélyét arra. hogy ők is kielégithessék szükségleteiket (Közös jövönk 1987). A fenntartható fejlödés három alappilléren nyugszik: a szociális, a gazdasági és a környezeti pilléreken és mindhármat együttesen, kölcsönhatásaik figyelembevételével mérlegelni kell a különbözỏ fejlesztési stratégiák, programok kidolgozása során, illetve a konkrét intézkedésekben, cselekvésekben. A fenntartható fejlődés, mint általános stratégiai cél 'bevonult' a nemzetközi konferenciák, szervezetek dokumentumaiba és a nemzeti kormányok cselekvési programjaiba. A fenntartható fejlődés fogalmáról, lényegéröl számos elemzés, vitairat látott napvilágot. Herman Daly (1990) szerint a fenntartható fejlödés a folytonos szociális jólét elérése, anélkül, hogy az ökológiai eltartó-képességet meghaladó módon növekednénk, tehát a szociális jólét, a méltányos életfeltételek lehetőségének biztositása mindenki, egyaránt a jelenlegi és a jövőbeli nemzedékek számára, ami csak úgy lehetséges, ha közben fenntartható módon hasznositjuk a természeti eröforrásokat, elkerüljük a káros hatásokat, $\mathrm{s}$ különösen a környezet állapotában bekövetkező visszafordíthatatlan változásokat. A Világ Tudományos Akadémiáinak Nyilatkozata megfogalmazásában: „, A fenntarthatóság az emberiség jelen szükségleteinek kielégitése, a környe- 
Géró Imre : Fogyasztási szövetkezeti kereskedelem és gazdaságpolitika tegnap, ma és holnap. Tér és Társadalom 22. évf. 2008/2. 145-167. p.

TÉT XXII. évf. 2008 - 2

Gyors ténykép

157

zet és a természeti erőforrások jövö generációk számára történö megőrzésével egyidejüleg". $(2000,1)$

A fenntartható vidékfejlesztés az agrárgazdaság és ezen belül a mezőgazdaság, illetve élelmiszer-termelés fenntartható fejlödésénél tágabb fogalomkör, de azokkal szoros összefüggésben áll, mert magában foglalja a vidéki lakosság és a vidéki települések nem mezögazdasági jellegủ tevékenységi köreit is, amelyek sok esetben az agrárgazdaság fenntartható fejlődésének nélkülözhetetlen elemei. A fenntartható fejlődésnek az életminőség és az életfeltételek javitását kell célul kitüznie (Láng 1997).

\section{Helyzetelemzés}

Magyarországon a Rió-i konferencia után, 1993-ban kormányhatározattal hozták létre a Fenntartható Fejlődés Bizottságot a konferencián elfogadott programokból és egyezményekből adódó hazai feladatok meghatározására és a végrehajtás koordinálására. A tárcaközi bizottságban valamennyi tárca képviselteti magát, továbbá több országos hatáskörü szerv és civil szervezetek képviselöi is helyet kaptak e testületben. Az elmúlt évtizedben megjelentek a fenntartható fejlődés egyes elvei és eszközei a különbözö ágazati tervekben. Az 1995-ös környezetvédelmi törvény, illetve az 1997-ben elfogadott és a 2002-ig terjedő időszakra készült Nemzeti Környezetvédelmi Program a fenntarthatóság elveire, integrált megközelítésére épült. Ez a szemlélet jellemzi a 2003-2008-as időszakra készült 2. Nemzeti Környezetvédelmi Programot is. A fenntartható fejlödés alapelvei, szemlélete azonban még tíz évvel a Rió-i konferencia után sem váltak általánosan elfogadottá. Ennek egyik alapvető oka valószínúleg az emberek szemléletében és a fenntarthatóságra vonatkozó ismeretek hiányában kereshető. A fogyasztás-központú szemlélet terjedése, a jólét fogalmának elsősorban az anyagi javakra történő korlátozása, a természeti erőforrások fokozott felhasználása a fenntarthatóság ellenében hat. Nem terjedt el a fenntartható fejlődés egyik legfontosabb feltétele, az átfogó szemléletmód, a társadalom - gazdaság - környezet kölcsönhatásait kiegyensúlyozottan figyelembe vevő, kezelő tervezés és irányítás. Ehhez járul hozzá az ágazatokra osztott igazgatási és intézményrendszer kellő mértékủ összhangjának hiánya és az összefüggéseket nem megfelelő módon bemutató tantárgy-központú, tudományág-alapú oktatás is. Az iparban végbement szerkezeti változások a termelés általános hatékonyságát tekintve kedvezőnek mondhatók, s ezt az anyag- és energiatakarékosság, növekvő minőségi követelmények és javuló környezeti mutatók jellemzik. A környezeti irányitási rendszerek is elterjedőben vannak. A legtöbb nagy cég és egyre több kis- és középvállalkozás fogadott el integrált környezetvédelmi programot, és szerzett ISO 9000 vagy 14000 minősítést. Az elmúlt évtizedben tapasztalt gazdasági fellendülés a társadalom jelentős hányadában a jövedelem növekedését eredményezte, ugyanakkor egyre növekszik az elszegényedő csoportok és a feltörekvö rétegek közötti szakadék. A gazdasági átalakulást kísérő kedvezőtlen társadalmi-gazdasági jelenségek (magas infláció, növekvő munkanélküliség, hajléktalanok, romló egészségi mutatók, az egyes régiók közötti jelentős fejlettségbeli különbségek) hatásai ma is érez- 
Géró Imre : Fogyasztási szövetkezeti kereskedelem és gazdaságpolitika tegnap, ma és holnap.

Tér és Társadalom 22. évf. 2008/2. 145-167. p.

hetök, de már jelentős mértékü kedvezö változásokat is tapasztalhatunk (pl. az infláció és a munkanélküliség csökkenése). Az életminőségben végbemenő változások értékelése azonban nem szorítkozhat csupán a jövedelmi viszonyok elemzésére. A gazdaságban érezhetö elönyös változások mellett nem feledkezhetünk meg a kedvezőtlen hatásokról sem. A gazdaság fejlesztése gyakran a környezet rovására történt/történik (zöldmezös beruházások, autópálya építések környezeti hatásai, települési zöldfelületek beépítése), nem minden vállalkozás érdekelt a természeti erőforrások fenntartható használatában, a szennyezőanyag-kibocsátás okozta környezeti károkat nem ellensúlyozza, nem ellensúlyozhatja a gazdaság által termelt nyereség. A jogi és közgazdasági szabályozók betartatása és továbbfejlesztése mellett a szemléletmód gyökeres megváltozása is szükséges.

\section{Fogyasztási szövetkezeti kereskedelem}

Hazai viszonyok között a szövetkezés ma identitási zavarral küzd. Az elmélet és a gyakorlat sokszor és sok helyütt egymással ellentétben áll. Az összhang biztosítása sokak müve lehet. A legföbb letéteményesek azonban maguk a szövetkezö tömegek. Szerepet játszanak benne a szövetkezeti és az állami intézmények, egészében a társadalmi és a gazdasági körülmények. A korrekciók bekövetkezhetnek spontán és tudatos cselekvés eredményeként. Alulról és felülröl is történhet a kezdeményezés. Folyamatosan vagy lökésszerúen valósulhat meg az állapotmódosulás. A cselekvés konkrét tartalmát és irányát az határozza meg, hogy milyen érdekek és milyen kényszerek húzódnak meg a változások mögött. Ezért a gyakorlat módosulása egyformán jelenthet elörelépést, csakúgy, mint visszavonulást, térvesztést, a szövetkezők alapvágyainak a korlátozását. Ez utóbbi mögött a politika, az állam, a piac mesterkedése állhat, netán tudatos szövetkezetellenesség húzódhat meg. Ma is sok tényező okoz aszinkront. Ezek külön-külön, vagy egymással csoportosulva fejezik ki gátló hatásukat. Az összhang hiánya azonban nem feltétlenül korszerütlenségre utal. $\mathrm{Az}$ alapideák ugyanis változatlanul vonzó emberi és társadalmi törekvéseket fejeznek ki. A megváltozott társadalmi és gazdasági viszonyok, döntően a tőke túlhatalma, illetve az öldöklő piaci verseny ugyanakkor eröteljesen korlátozza, vagy lehetetlenné teszi e nemes célok követését. Ezért, vagy ennek ellenére, választ várnak az alábbi kérdések:

1) A helyzetet olyannak tekintsük-e, amely a kialakult viszonyok újraértelmezését igényli, mivel végérvényes helyzettel, megerösödött tendenciával állunk szemben?

2) Továbbra is tartsuk-e iránytünek a szövetkezeti értékeket és elveket azért, mert a tökés környezet $s$ annak minden következménye célszerüsíti a kisembereknek e keretek közötti összefogását, elsősorban a fenntartható fejlődés és vidékfejlesztés összefüggés-rendszerében?

A gyakorlat adhat választ. Az emberek összefogása, tenni akarása, az önszerveződés, a demokratikus müködés, a szükségletek jobb és olcsóbb kielégítésének igénye, az aktivitás és a jövedelemszerzés vágya számottevő erőként mutatkozik meg a 
Géró Imre : Fogyasztási szövetkezeti kereskedelem és gazdaságpolitika tegnap, ma és holnap.

Tér és Társadalom 22. évf. 2008/2. 145-167. p.

TÉT XXII. évf. 2008 a 2

Gyors ténykép

159

szövetkezés keretei között. Új esélyek nyílhatnak. A megbomlott egyensúly javításában vagy helyreállításában a lehetőségekből (a realitásokból) indulhatunk ki. Az egyes szövetkezetekben $\mathrm{s}$ a mozgalmon belül a szubjektív elhatározás, a jobbító szándék adott. A fékek ugyanakkor sokrétủek és hatásosak:

1) hiányzik az anyagi feltétel;

2) magas az állami elvonás;

3) korszerüek és tőkeerösek (a hazánkba betelepült) multinacionális cégek;

4) visszaesett a szövetkezeti termelői aktivitás;

5) fokozódik a kínálat;

6) eröteljesen differenciálódott (a fogyasztói piacon) a kereslet.

Olyan verseny bontakozott ki (a termelésben és a realizálásban egyaránt), amely korlátozza a szövetkezetek müködését azon területeken és népességcsoportokban (a tagság körében), ahol eddig természetes szerveződésként ágyazódtak be. Milliók esélye és lehetösége rendült meg az öntevékeny összefogásban, a sorsukért való önszerveződésben. Mindez a munkanélküliséggel s a létbizonytalansággal is összekapcsolódott. Ez már túlmutat a szövetkezés térvesztésén, elméletének és gyakorlatának a konfliktusán. Az uralkodó politika, a hatalom feladatkörébe tartozó társadalmi- és piacépítő szerepkör gyengeségére is utal. Az állam tehát nem lehet közömbös. Feladata egyértelmű és körülhatárolt. A belső (a szövetkezeti) cselekvés és a külső (az állami) közremüködés együtt lehet a garanciája a szövetkezés útjában álló akadályok lebontásának. Ez a kölcsönösség azonban nem jelentheti a felelősség elhomályosítását, az egymásra mutatást és a várakozást. A gyakorlat minden tényezőjének, elsősorban a cselekvő résztvevőknek, a szövetkezőknek megvan a csakis rájuk tartozó kötelessége, amelyet kinek-kinek maradéktalanul el kell látnia. Így állhat össze a részekből az egész, bontakozhat ki a megújulás, az egymást támogató vagy revidiáló elmélet és gyakorlat. Ezzel együtt számolnunk kell azzal is, hogy a szövetkezetek és szervezeteik soha nem voltak és nem is lesznek független, elszigetelt jelenségek a társadalmakban. Azok mindig a külső feltételrendszerbe ágyazódnak, $\mathrm{s}$ abban is fejeződnek ki. Bennük a gazdasági és a piaci viszonyok, a demográfiai tényezök, illetve a tulajdonformák, általában a társadalmi körülmények visszatükröződnek. Ezek közül az állami magatartás emelkedik ki. Ez a szövetkezés egyik Achillesi pontja. Az elmélet és a gyakorlat egyik próbaköve. Ugyanilyen fontossággal bír az is, hogy maguk a szövetkezők a lehetőségeikkel miképpen élnek. A szövetkezés kínálta perspektívát tehát nemcsak a külső feltételek, hanem a belső adottságok is determinálják. A szóban forgó viszonyrendszer azonban rendkívül bonyolult. Az önkifejeződés kiemelt fontosságára és folyamatosságának elsődlegességére mindenesetre rámutat az, hogy hazánkban gyökeret vert a szövetkezés magja, a hajtás szárba szökkent, $\mathrm{s}$ az fává terebélyesedett. Ez a tény egyértelműen arra utal, hogy a fennmaradás és a müködés alapvető garanciája mindig is az élni akarás, $\mathrm{s}$ az ennek érdekében kibontakozó belső hajtóerő volt. A múlt tehát azt bizonyítja, hogy a belsỏ kohézió, a szükség munkálása olyan összetartó, illetve feszitỏ erő, melynek kifejezésére a szövetkezés a változó körülmények között is esélyt adott. A tanul- 
Géró Imre : Fogyasztási szövetkezeti kereskedelem és gazdaságpolitika tegnap, ma és holnap.

Tér és Társadalom 22. évf. 2008/2. 145-167. p.

mány terjedelmi korlátai miatt a Coop-üzletlánc fejlődése jellemzőinek részletes taglalására e helyütt nem kerülhet sor. A programalkotás, a cselekvés és az érdekérvényesítés képessége viszi előre, illetve tartja együtt az embereket. Szük csoportjaiknak, illetve tömegeiknek egyformán alternatívát nyújt a szövetkezés. A vele öszszefüggő befolyás ezért választóvíznek bizonyul, s a hétköznapokban:

- kölcsönösség vagy szembenállás;

- elóremozgás vagy tehetetlenség;

- leépülés vagy terjeszkedés;

- kevesek vagy sokak boldogulása valósul meg annak keretei között.

A gyakorlat így szükségszerüen mindig is ,tarka képet” mutatott, $\mathrm{s}$ ma is ilyen a helyzet. A történések tehát az önszervezésen alapuló belső cselekvés mikénti fontosságára utalnak. Ez érdeket és egyben kényszert fejez ki. A légüres tér a piacon ugyanis hamar kitöltődik. Az a kérdés és egyben a tét, hogy kik nyomulnak előre. Egyesek vagy csoportok, egyesek vagy a tömegek vágya és érdeke teljesül-e. Létezik persze jó kompromisszum. Ha viszont a sokak kenyere és a kevesek profitja között húzódik a választóvonal, akkor a szövetkezeti összefogás, szolidaritás viszszaszorulása miatt a társadalom a vesztes. A gyakorlat összehangolása tehát a környezet kínálta előnyök kihasználását jelenti a belső anyagi és szellemi erők mobilizálása és sikeres hasznosítása alapján. Az ilyenfajta cselekvés mindig is többesélyes volt és az is marad. Néhány változatot az alábbiak is szemléltetnek:

1) A kedvezőtlen külső környezeti hatásokat a belső erőfeszitések, a sikeres cselekvés ellensúlyozhatja. Talpon maradás vagy fejlődés az eredmény.

2) A rossz külső feltételek korszerütlen belső viszonyokkal fonódnak össze. Tétovázás, perspektívanélküliség, megkésett cselekvés vagy helytelen orientáció, stagnálás, a visszacsúszás, netán a felbomlás a következmény.

3) A kínálkozó külső lehetőségek jól kifejezödnek a belső viszonyokban. A szövetkezésben rejlö előnyök csak tovább gerjesztik a folyamatokat, növelik a teljesítőképességet, javul a hatékonyság. Önfejlödés s akkumuláció valósul meg.

E variációk mindegyike a szövetkezetek és szervezeteik öntevékeny cselekvésének fontosságára utal. Olyan magatartásra hívja fel a figyelmet, amely elörelátást, tudatosságot, tervszerủséget, mában és holnapban való gondolkodást fejez ki. Középpontjában a teljesítmény és a hatékonyság áll.

\section{A rendszerváltás utáni szervezeti innováció fóbb jellemzői $i^{2}$}

Az évtized fordulóján politikai rendszerváltás történt. A szövetkezeti kereskedelem számára minden tekintetben ellentmondásos helyzet alakult ki. Az áfészekben (Általános Fogyasztási és Értékesítő Szövetkezet) hagyományokra és gazdag tapasztalatokra alapozott volt a mezőgazdasági termeltetés, felvásárlás és feldolgozás, hiszen korábban hozzájuk kapcsolódtak az alacsonyabb típusú termelöi társulások. Tagjainak pótlólagos jövedelmet jelentett a mezőgazdasági aktivitás. Az áfészek számára viszont vásárlóerő-bővülést, tagi kötődést eredményezett a kiegészítő tevé- 
Géró Imre : Fogyasztási szövetkezeti kereskedelem és gazdaságpolitika tegnap, ma és holnap.

Tér és Társadalom 22. évf. 2008/2. 145-167. p.

TÉT XXII. évf. 2008 - 2

Gyors ténykép

161

kenység, hiszen a falusi lakosság jelentős hányadára kiterjedő kistermelői kooperáció valósult meg. Az áfészek - szinte kivétel nélkül - (helyenként tagérdekból) szervezték ezt a munkát. Kialakították az e tevékenységre szakosodott helyi és országos közös vállalataikat.

Az 1990-es évek elején (a rendszerváltással párhuzamosan) összeomlott a piac, a tulajdonviszonyokban alapvető változások történtek, megszünt a „keleti kapcsolat”. A Kormány rendeleti úton feloszlatta a szakcsoportokat. Sok áfészt a hátra maradt kötelezettségek megrendítettek. Döntő többségük a strukturális váltás keretében a mezőgazdasággal összefüggő minden tevékenységből kivonult. Ez is hozzájárult ahhoz, hogy müködési területükön lecsökkent a fogyasztói potenciál. Meglazultak a tagsági kapcsolatok. A napicikk-forgalmazásra történő szakosodás - sok összetevő együttes hatására - leszükítette az áfészek mozgásterét. Szük keresztmetszetek és kényszerpályák alakultak ki, régiónként eltérések voltak tapasztalhatók. Az áfészek számára ezek a külső körülmények kedvezőtlen hátteret nyújtottak. Az adott idöszakban tehát nem várt korlátok támadtak, $\mathrm{s}$ bizonytalan perspektívák mutatkoztak. Ezek a legitimitásra, a státuszra, a szövetkezeti jelleg újraértelmezésére, a szerepkörre, a felelősség-módosításra, a tevékenységi struktúra átrendeződésére, $\mathrm{s}$ végül a külső és a belső kapcsolatok korrekciójára egyaránt vonatkoztak. Arra irányultak, hogy a szövetkezeti kereskedelem a megváltozott társadalmi-gazdasági helyzetben is tartsa meg pozícióit, teljesítőképességét, fokozza a tagsági szolgálatot, s gerjessze a tulajdonosi és a fogyasztói érdekeltséget. A kialakult helyzetben, a növekvő gazdasági versenyben ezek a célok - nagy erőfeszítések árán - az 1990-es években csak részben valósulhattak meg. A szövetkezeti kereskedelemben széles körü racionalizálást hajtottak végre. Az áfészek irányt vettek a korszerú élelmiszerkereskedelem, az iparcikk-kereskedelem és a mezőgazdasággal kapcsolatos szolgáltatás (gazdabolt-hálózat) kifejlesztése felé. Az évtized elejẻn a korszerüsítés bázisát 11552 áfész kereskedelmi szervezet (közte 95 áruház, 1012 szupermarket és 6520 élelmiszerbolt) jelentette. Az áfészek mintegy 120Mrd Ft-os árbevételének döntő részét (az évtized közepén) a bolti kiskereskedelmi tevékenység adta. Az élelmiszer-, a napicikk-forgalmazás értéke meghaladta a 60Mrd Ft-ot. Az áfészek ezen nagyságrendjükkel a magyarországi kiskereskedelemböl $10 \%$ körüli részarányt képviseltek. A kisebb településeken lévő boltjaikat - igazodva a körülményekhez, a gazdasági viszonyokhoz - jórészt bérletes formára szervezték át. Ugyanakkor az általuk müködtetett nagyobb alapterületü $\mathrm{ABC}-\mathrm{k}$, élelmiszerboltok technikai, müszaki megújítását, egységes arculatának kialakítását elvégezték. Ennek érdekében az egyes áfészek tulajdonában lévő egységeket közös érdekből integrálták, ami biztosította az egységes piaci fellépést a beszerzésben, a marketing-, reklámmunkában, az áruválasztékban, a technológiában, a szakértelemben, - a közös beszerzés bővülésével pedig lehetöség szerint - az árpolitikában. Az áfészek az élelmiszer, a napi cikkek körére alapozva az évtized derekára befejezték a megyei (regionális) közös szövetkezeti beszerzỏ szervezetek (Pro-Coop-ok) létrehozását. Forgalmuk éves szinten ez idöszakban mintegy 12Mrd Ft-os nagyságrendet tett ki, ami meghaladta az áfészek élelmiszer-, napicikk-forgalmazásának egyötödét. 
Géró Imre : Fogyasztási szövetkezeti kereskedelem és gazdaságpolitika tegnap, ma és holnap.

Tér és Társadalom 22. évf. 2008/2. 145-167. p.

Integrációs erőfeszítések (1995-97). A piacon maradás, a versenyben való helytállás egyik feltétele a nagybani beszerzés továbbfejlesztése, pénzügyi, technikai hátterének korszerüsítése, logisztikai rendszerbe való foglalása lett az évtized második felében. Annak a célnak a megvalósítása, hogy e rendszer valamennyi térséget átfogja, ahol szövetkezetek müködnek, s ez által az áfészek nagyvevöként jelenjenek meg a kereskedelem korszerüsítését támogató kormányprogramban lévő lehetőségek terén, $s$ jó eséllyel pályázzanak az állami tulajdonú egyes FÜSZÉRT vállalatok privatizációjában.

A Pro-Coop rendszer kiépitése eredményesen fejeződött be, amihez a Coopbolthálózat sikeresen kapcsolódott. Mindez további ösztönzést adott a szövetkezeti kiskereskedelmi integráció fejlesztéséhez. („,Kis magyar kereskedelmi csoda”-ként említik a láncba szervezódött kis bolthálózat magyarországi integrációját, - mint szervezeti innovációt -, az EU tekintélyes kereskedelmi szakértői is). Ezzel összhangban az áfészek megyei (regionális) közös beszerzési szervezeteinek, a Pro-Coopok-nak az összefogását az Országos Szövetség, az ÁFEOSZ látta el. Koordinálta az egyes régiókban müködő közös szervezetek árubeszerző tevékenységét. Az ÁFEOSZ ma is képviseli az áfészeket, azok beszerzési szervezeteit a nemzetközi szövetkezeti árukapcsolatokban, az import területén. Tagként vesz részt a Szövetkezetek Nemzetközi Szövetségének (az SZNSZ-nek) szakosított beszerzési szervezetében, az InterCoop-ban. Ezáltal is erősíti a döntően nyugat-európai szövetkezeti bázison müködő szervezettel a magyarországi szövetkezeti kereskedelem kapcsolatait. Ez is részévé vált (az adott időszakban) a gazdasági érdekképviseleti tevékenységnek, melyre a kialakult piaci viszonyok között az áfészekben alapvető szükséglet mutatkozott. A formálódó, a privatizáció révén jórészt külföldi tulajdonba került iparcikkkereskedelemmel folytatott versenyben az áfészek kialakították az áruházak, iparcikkszaküzletek összefogását, irányítását. Az egyes áfészek tulajdonában lévő mintegy 100 áruház s közel 400 nagyobb alapterületủ iparcikkbolt jelentette azt a bázist, amelynek üzletlánccá szervezése révén versenypozícióikat erősítették, s ez az adott régióban hozzájárulhatott a tagság, a lakosság színvonalas kereskedelmi ellátásához.

A piaci verseny, az új versenytársak megjelenésének hatására az áfészek célul tủzték ki belső szervezetük innovációját, megủjítását versenyképességük megőrzése érdekében. Ez mindenekelőtt a struktúra olyan irányủ módosítását $\mathrm{s}$ az eróforrások olyan átcsoportosítását jelentette, amely előtérbe helyezte az élelmiszer-, a napicikk-kereskedelmet. Magában foglalta a vezetési, a szervezési rendszerek korszerúsítését, a számítástechnikai eszközök széles körü alkalmazását, a hálózati egységek integrált irányítását, a hatáskörök átrendezỏdését, $\mathrm{s}$ végül a központi irányítás szakmai színvonalának, hatókörének növelését.

Az előbbieken túlmenỏen a szövetkezeti kereskedelem technikájának, technológiájának korszerüsítésére is sor került, melynek révén az áfészek nagyszámú, 17 ezer boltból álló kiskereskedelmi hálózatának jelentős része azonos megjelenést és arculatot kapott. A szövetkezeti kereskedelem egységes nagybani beszerzésének és el- 
Géró Imre : Fogyasztási szövetkezeti kereskedelem és gazdaságpolitika tegnap, ma és holnap.

Tér és Társadalom 22. évf. 2008/2. 145-167. p.

TÉT XXII. évf. 2008 a 2

Gyors ténykép

163

osztási rendszerẻnek biztosítása céljából az áfészek 1997-ben országos részvénytársaságot hoztak létre. Ez az új gazdasági szerveződẻs a régiókban működő ProCoop-okkal (1. ábra) megfelelő munkamegosztást alakított ki, sủj esélyt biztosított a szövetkezeti kereskedelem számára az erősödő belföldi piacon.

\section{1. ÁBRA}

Az integrált szövetkezeti nagykereskedelmi régiók

(The Integrated Wholesale Regions of Hungarian Coop-Brandstore Network)

ÉSZAK-KELET PRO-COOP RT.

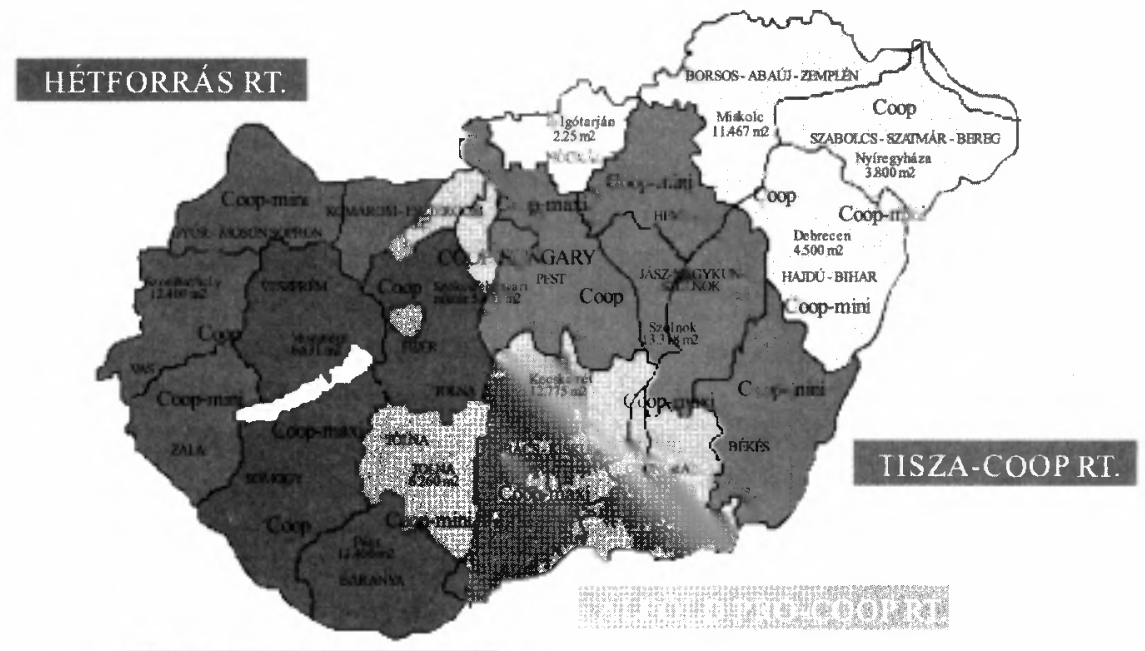

MECSEK FÜSZÉRT RT.

Forrás: Coop-Hungary Rt. (2005).

A mai gyakorlatot $\mathrm{s}$ a jövő programját, az ehhez kapcsolódó érdeket két gyakorlati szempont (realitás) motiválja: egyrészt az, hogy az általános fogyasztási értékesítő és beszerző szövetkezetek (áfészek), illetve struktúrájuk jórészt már kialakult, az új körülményekhez igazodott. Az áfészek jelen vannak a kisfalvakban éppen úgy, mint a nagyvárosokban. Tevékenységük az élelmiszer- és a napi cikk ellátás körében racionalizálódott. E feladatok sikeres ellátása érdekében üzlethálózataikat átalakították, beszerzési és értékesítési láncokat és elosztó központokat szerveztek. Az említett áfészek tulajdonlásában $6000 \mathrm{ABC}$ és áruház Mini-Coop, Coop és MaxiCoop rendszerben müködik (2. és 3. ábra). Emellett nagyrészt korszerüsödött a gazdabolt- és vegyesiparcikk-ellátó hálózat. További 1000-1500 kisüzlet és egyéb ellátó, szolgáltató egység bérleti dijjas rendszerben tevékenykedik. A szakosodás ellenére még mindig jelentös élelmiszer-feldolgozó kapacitás áll a mozgalom rendelkezésére. 
Géró Imre : Fogyasztási szövetkezeti kereskedelem és gazdaságpolitika tegnap, ma és holnap.

Tér és Társadalom 22. évf. 2008/2. 145-167. p.

164 Gyors ténykép

TÉT XXII. évf. 2008 a 2

\section{2. ÁBRA}

A COOP (ÁFÉSZ) Csoport bevételének alakulása 1997-2005 között

(The Return from Sales' Development of the COOP [General Consumer's Cooperation] Group 1997-2005)

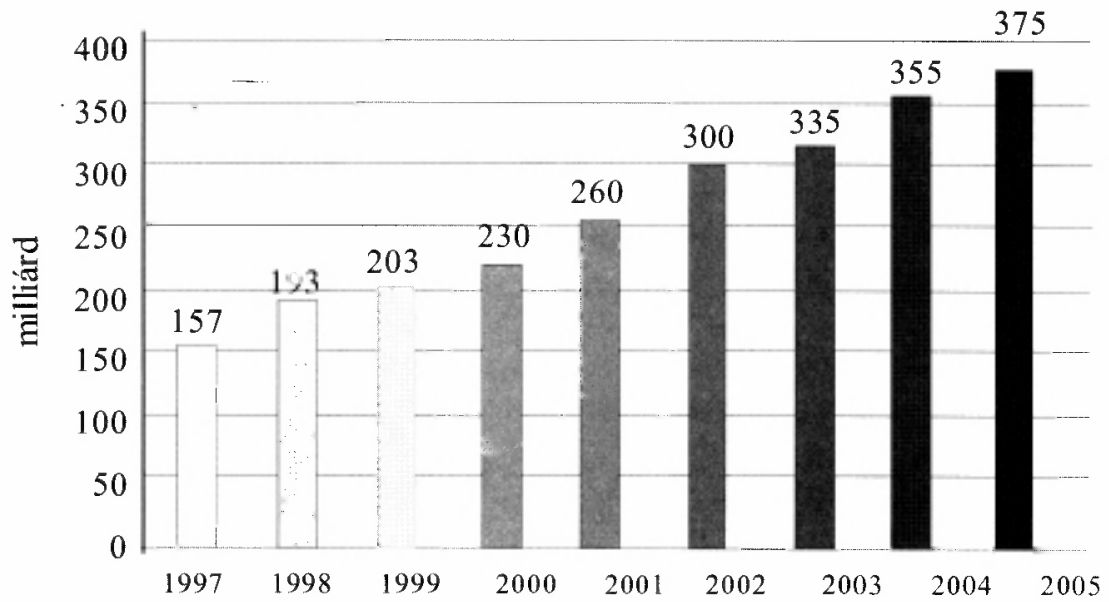

Forrás: Coop-Hungary Rt. (2005).

\section{3. ÁBRA}

A COOP üzletlánc versenyképessége - Image index versus piaci részesedés, 2004

(Compatitiveness of the COOP - Image Index vs. Market-share, 2004)

Piaci részesedés (\%)

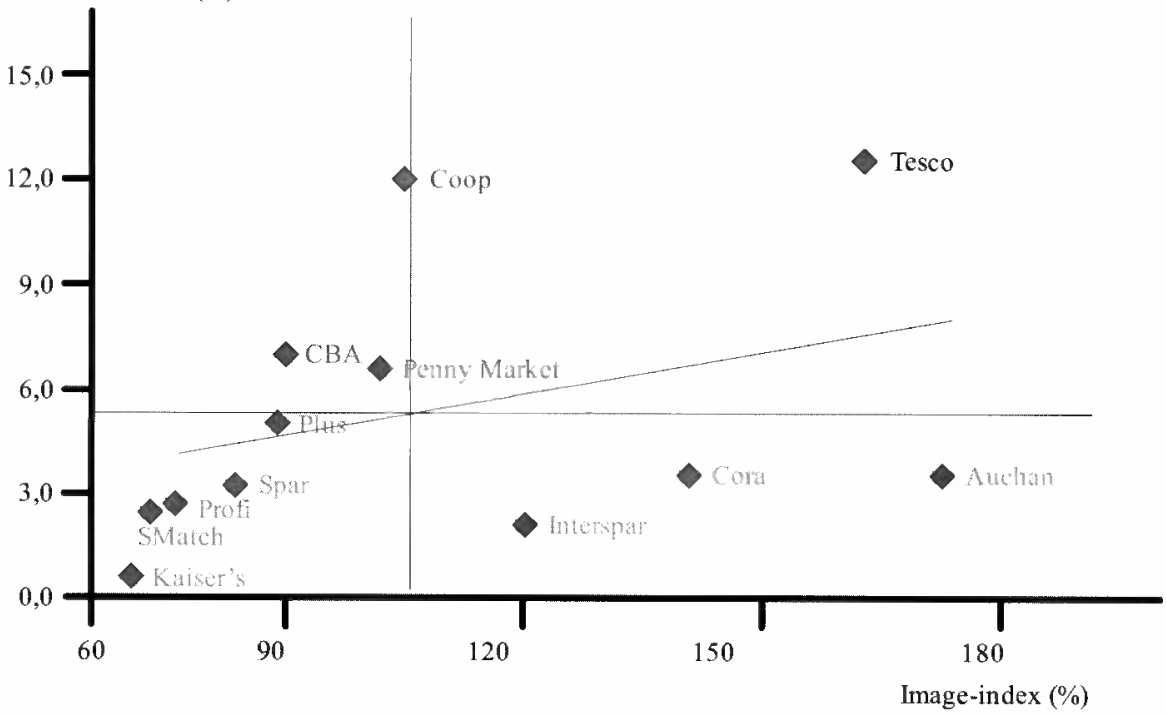

Forrás: GfK Hungária Coop üzletlánc image-vizsgálata és ConsumerScan (2004). 
Géró Imre : Fogyasztási szövetkezeti kereskedelem és gazdaságpolitika tegnap, ma és holnap.

Tér és Társadalom 22. évf. 2008/2. 145-167. p.

TÉT XXII. évf. 2008 — 2

Gyors ténykép

165

\section{Összefoglaló - gondolatok a jövöbeni cselekvés (stratégia) lehetséges irányairól}

A tanulmányban elsődlegesen elméleti oldalról igyekeztünk vizsgálni a magyar fogyasztási szövetkezeti kereskedelem helyzetét. Az EU szintjén is kétségtelen sikereket felmutatni tudó magyar fogyasztási szövetkezeti kereskedelmi hálózat szerepe és jelentősége azonban jóval túlmutat azon a kizárólagos „kereskedelmiszakmai téren", amelyet ágazati szakmai szempontból a bolti kiskereskedelem és a logisztikai funkciókat betöltö Pro-COOP rendszer létrehozásával elért a „vidék" meghatározó kereskedelmi üzletlánca. A vidéki magyarországi hagyományainál fogva, valamint a szövetkezésben rejlö értékekre és alapelvekre alapozva egy teljesen új marketing gondolkodásmóddal felépített stratégia segítségével, véleményünk szerint, középtávon gyökeres fordulat érhetố el a fogyasztási szövetkezeti kereskedelem és általában a szövetkezés társadalmi megítélése tekintetében a jövőben. Mindehhez új mérfôldkövet jelentett 2005. december 19-e, a magyarországi szövetkezetek törvényi szabályozása története vonatkozásában. A Magyar Köztársaság Országgyülése elfogadta a szövetkezetekről szóló 2006. évi X. törvényt, melyet a hosszas előkészítés során a Kormány az országos szövetkezeti ágazati érdekképviseletek és az OSZT (Országos Szövetkezeti Tanács) szoros együttmúködése előzött meg. Az Országos Szövetkezeti Tanács érzékenyen reagált a változások iránti igényre és kereste annak lehetőségét, hogy miképp lehetne a szövetkezeti jogos elvárásokat orvosolni. 2003 tavaszán a Nemzetközi Szövetkezeti Napra történő előkészület jegyében az OSZT vezetö személyiségei sorra látogatták azokat a tárcavezetőket, akik a szövetkezeti törvénykezésben meghatározó befolyással rendelkezhetnek. Mind a Miniszterelnöki Hivatal, mind a Földmüvelésügyi és Vidékfejlesztési Minisztérium kedvezően fogadta az OSZT azon törekvését, hogy a Kormány érdemben foglalkozzon a szövetkezetek ellehetetlenítését célzó 2000 . évi szövetkezeti törvény módosításával, új szabályozással állítsa helyre az érdekképviseleti jogosítványokat, keresse a törvénymódosítás útján az üzletrészek okozta gondok felszámolását és rendeződjék végre a szövetkezetek több törvény általi szabályozásának kuszasága (Farkas 2006).

Meghatározó volt az OSZT kezdeményezésének jelentősége abban, hogy a Magyar Köztársaság Kormánya a szövetkezetek részéről megjelenö jogos igények orvoslására több lépcsőből álló munkaprogramot fogadott el (pl. Szövetkezetpolitikai Kollégium megalakulása 2003. október 28-án stb.). A Szövetkezetpolitikai Kollégium megvalósulása egyik legnagyobb érdemének tekintjük - a fogyasztási szövetkezeti kereskedelem kutatójaként - azt, hogy felszínre hozta a szövetkezésnek, mint a civil társadalom új eszközének újragondolását, a szövetkezeti demokrácia alapján a globalizáció káros elemei elleni küzdelem lehetôségét (Farkas 2006).

A másik fontos aspektus, amelyet örömteli módon a törvényalkotók is felismertek, hogy ,a szövetkezetek a foglalkoztatáspolitika, a regionális, a vidékfejlesztési, az agrár-, s a környezetvédelmi politika keretei között felmerülő problémák megoldásának, de legalábbis kiegyensúlyozásának az eszközét is jelentik ... figyelmet kell fordítani 
Géró Imre : Fogyasztási szövetkezeti kereskedelem és gazdaságpolitika tegnap, ma és holnap. Tér és Társadalom 22. évf. 2008/2. 145-167. p.

TÉT XXII. évf. 2008 - 2

arra is, hogy az utóbbi idöben több nemzetközi fórum napirendjén szerepelt a szövetkezés ügye" (Karácsony 2006, 10). (Mindezekre a tanulmány egy korábbi részében már részletesen utaltunk.) Ezek a fórumok a szövetkezeteket a globalizálódó világ korrekciós mechanizmusaként fogják fel, amellyel mélységesen egyetértünk.

A fogyasztói értékorientáció, - mint paradigmaváltás a marketing diszciplínában - vezérfonalát felhasználva célszerünek tünik egy olyan mélyreható kutatás elvégzése, amely válaszokat tudna adni a szövetkezetiség jelen korunkbeli és a jövő trendjeiből származtatható legfontosabb kérdéseire. Pl. miért érdemes szövetkezetet létrehozni és hogyan?; miért érdemes szövetkezeti tagnak lenni, és milyen feltételekkel?; milyen ténylegesen felmerülö szükségleteit elégíthetné ki, - illetve kellene, hogy kielégítse - a fogyasztóknak, a szövetkezeti tagságnak egy új, innovatív modellre épülö fogyasztási szövetkezeti vállalkozás, s milyen marketing eszközöket kellene alkalmazni ahhoz, hogy az új szövetkezeti tagság örömmel csatlakozzon ehhez az új szövetkezeti modellhez? stb. A szükségleti hierarchiát, mint „értékláncot" kezelve az új marketingkoncepció alapján bizonyitható, hogy teljesen új gondolkodásmódra van szüksége - véleményünk szerint - a fogyasztási szövetkezetek elméletével foglalkozóknak. Példaként említjük meg, hogy a mai magyar fogyasztási szövetkezeti kereskedelem ,abszolút” versenyhátránya a multinacionális kereskedelmi üzletláncok hipermarketeivel szemben, hogy nem tud „mindent egy helyen kínálni”. Tehát a legújabb marketing koncepció alapján a vevő/szövetkezeti tag számára olyan új értékeket (vevőértéket) kell létrehozni egy új szövetkezeti modell segítségével, ami vonzóvá teszi számára az új típusú szövetkezeti formációt és örömmel csatlakozik hozzá. Milyen lehet ez? Például egy lehetséges elméleti modell: egy olyan diverzifikált vállalkozás (Diver-Coop), amelyben a kereskedelem mellett az agrárgazdaság (agribiznisz), élelmiszertermelés és forgalmazás vertikuma (a vidékfejlesztés integrátoraként), szolgáltatások széles köre, kulturális, egészségügyi és oktatási szolgáltatások komplex, diverzifikált új rendszere alkothatja azt a 21. századi új szövetkezeti modellt, amely az Internet segitségével a szövetkezeti hálózatokkal analóg módon abszolút versenyképes partnere lehet a globalizált világnak. Ugyanis egy olyan újszerü ,hálózatok hálózatát” lehetséges létrehozni a szövetkezés alapgondolatára, alapelveire és alapértékeire alapozva, amely egy teljesen új fogyasztási szövetkezeti modellként hosszú távra megalapozhatja a szövetkezeti rendszer versenyképességét, szervezeti innovációjának fejlődését és a magyar gazdaságpolitika prioritásaihoz történő konvergenciáját. (E gondolatkörbe szervesen illeszthető a regionális vidékfejlesztés stratégiai kérdésköre, vagy pl. a kistérségek problematikája).

E gondolatok részletes kifejtése azonban már egy másik tanulmány feladata lehet.

\section{Jegyzetek}

${ }^{1}$ A fejezet Dedák István által irt A gazdasági felzárkózás néhány növekedéselméleti tanulsága címủ tanulmány alapján készült (Dedák 2003).

${ }^{2}$ A fejezet Fekete (2002) alapján készült. 
Géró Imre : Fogyasztási szövetkezeti kereskedelem és gazdaságpolitika tegnap, ma és holnap. Tér és Társadalom 22. évf. 2008/2. 145-167. p.

\section{Irodalom}

Bakacsi Gy.-Bokor A.-Császár Cs--Gelei A.-Kováts K.-Takács S. (1999) Stratégiai emberi erőforrás menedzsment. Közgazdasági és Jogi Könyvkiadó, Budapest.

Barro, R. J.-Sala-i-Martin, X. 1992) Convergence. - Journal of Political Economy. 2. 223-251. o.

Ben Ami, J. -Farkas F. (2003) Marketing and Management. - M\&M. 4. 32-36. o.

Bennis, W.G. (1969) Organization Development: Its Nature, Origins and Prospects, Reading. AddisonWesley Publishing Company, Massachusets.

Brown, R.L. (2001) Az éhezés gyökeres felszámolása. - A világ helyzete 2001. Worldwatch Institute, Föld Napja Alapítvány, Budapest.

Burke, W.W. (1994) Organization Development: A Process of Learning and Changing. Second Edition, Addison-Wesley Publishing Company, Massachusets.

Chikán A. (1997) Vállalatgazdaságtan. AULA Kiadó Kft. Budapesti Közgazdaságtudományi és Államigazgatási Egyetem, Budapest.

Chikán A.-Demeter K. (2003) Az értékteremtö folyamatok menedzsmentje. Budapesti Közgazdaságtudományi és Államigazgatási Egyetem, AULA Kiadó Kft., Budapest.

Collis, D.J.-Montgomery, C.A. (1995), Competing on resources - Strategy in the 1990's. - Harvard Business Review. July-August. 124-130. o.

Daly, H.E. (1990) Sustainable Growth: An Impossibility Theorem. - Development. 3-4. http://www.c3.hu/ bocs/eletharm/harpart/daly3pi.htm

Dedák I. (2003) A gazdasági felzárkózás néhány növekedéselméleti tanulsága. SZTE Gazdaságtudományi Kar, JATEPress, Szeged. 47-57. o.

Dobák M (1996) Szervezeti formák és vezetés. Közgazdasági és Jogi Könyvkiadó, Budapest.

Farkas T. (2006) A szövetkezeti jog új mérföldköve. - Szövetkezés. 1.4-5. o.

Fekete J. (2002) Az Áfészek átalakulása és integrált rendszerré szerveződése az elmúlt évtizedben. Szövetkezés. 1-2.36-54. o.

Ghemawat, P. (1986) Sustainable advantage. - Harvard Business Review. September-October. 53-58. o. http:// www. Brainyquote.com/quotes/authors/W/warren_g_bennis.html

Karácsony M. (2006) Új szövetkezeti törvény azaz lehetôség a társadalmi önszervezödésére és az önigazgatásra. - Szövetkezés. 1. 10. o.

Korompai, A. (1995) Regionális stratégiák jövökutatási megalapozása. Regionális Tudományi Tanulmányok I. ELTE Regionális Földrajzi Tanszék, Budapest.

„Közös Jövönk” Jelentés (1987) A ,fenntartható fejlődés” Stockholmtól Johannesburgig. ENSZ Környezet és Fejlödés Világbizottsága. - http:www. Ff3.hu/stock,html

Láng I. (1997) A magyar mezógazdaság fenntartható fejlődése - Lehetöségek és korlátok. - Kovács T. (szerk.) A fenntartható mezögazdaságtól a vidékfejlesztésig. IV. Falukonferencia, MTA Regionális Kutatások Központja, Pécs. 40-45. o.

Mankiv, G.-Romer, P.-Weil, D.N. (1992) A Contribution to the Empirics of Economic Growth. - The Quarterly Journal of Economics. 2. 407-437. 0 .

Miles, M.B.-Schmuck, R.A. (1989) The Nature of Organization Development in French. -Bell, C.H.awacki, R.A. (eds.) Organization Development: Theory, Practice and Research. Third Edition. Homewood, Illinois. 39. o.

Rechnitzer J. (1998) Területi stratégiák. Dialóg Campus Kiadó, Budapest-Pécs.

Smith, A (2007) An Inquiry into the Nature and Causes of the Wealth of Nations. Books I, II, III, IV, and V - http://metalibri. Incubadora.fapesp.br. Amsterdam-Lausanne-Melbourne-Milan-New YorkSao Paolo.

Veress J. et al (2001) Gazdaságpolitika. Budapesti Közgazdaságtudományi és Államigazgatási Egyetem, AULA Kiadó Kft., Budapest.

Versenyképességi koncepció. (2005) Munkaanyag. www.gkm.gov.hu/ data/8535/versenyképességi.pdf. Letöltve: 2005.10 .18 .

Világ Tudományos Akadémiáinak Nyilatkozata Deklarációja. (2000) A fenntartható fejlődésröl a johannesburgi konferencia kapcsán. Tokió. - http:// belsoudvar.hu/eppiac_0210pdf 